\title{
PEMAHAMAN ORANGTUA MENGENAI SAMPAH NON ORGANIK DAN PEMANFAATANNYA SEBAGAI MEDIA PEMBELAJARAN ANAK PRASEKOLAH
}

\author{
Rohita $^{1}$, Dewi Asnawiyah ${ }^{2}$ \\ ${ }^{1,2}$ Prodi Pendidikan Guru Pendidikan Anak Usia Dini \\ Universitas Al Azhar Indonesia \\ Jakarta, Indonesia \\ e-mail: rohita@uai.ac.id ${ }^{1}$
}

\begin{abstract}
Abstrak
Sampah masih menjadi permasalahan tersendiri yang menimbulkan dampak besar bagi lingkungan dan kesehatan. Sampah yang terbagi menjadi sampah organik dan sampah non organik terbanyak dihasilkan dari rumah tangga. Diperlukan pemahaman yang cukup agar orangtua mampu memanfaatkan sampah non organik dan menggunakannya sebagai media pembelajaran bagi anak usia prasekolah, selain juga untuk mengurangi sampah dan menjaga kelestarian alam. Penelitian ini bertujuan untuk mendeskripsikan pemahaman orangtua mengenai sampah non organik dan pemanfaatannya sebagai media pembelajaran anak prasekolah. Metode penelitian yang digunakan adalah metode deskrlptif kualitatif. Teknik pengumpulan data menggunakan wawancara, observasi, dan dokumentasi. Analisis data menggunakan teknik analisis model interactive Miles and Huberman yang mencakup tahap koleksi data, reduksi data, display data, dan verifikasi data. Penentuan subjek menggunakan teknik purposive sampling, dengan kriteria keluarga dengan anak usia 4-6 tahun yang dan bersedia menjadi responden penelitian. Adapun jumlah subjek dalam penelitian ini yaitu 15 orang tua dengan kriteria tersebut yang berlokasi di wilayah Tangerang Selatan, Banten. Hasil penelitian menunjukkan bahwa pemahaman orangtua mengenai sampah non organik dan pemanfaatannya sebagai media pembelajaran berada pada kategori baik, dimana responden mampu menjelaskan makna sampah non organik dengan benar; mampu membedakan dengan cara menyebutkan jenis sampah non organik dengan benar; mampu menjelaskan pentingnya melakukan daur ulang; dan mampu menyebutkan/ mencontohkan media pembelajaran yang dapat dibuat dengan memanfaatkan sampah non organik.
\end{abstract}

Kata-kata Kunci: Orangtua, sampah, non organik, prasekolah.

\begin{abstract}
Garbage is still a separate problem that has a big impact on the environment and health. Waste which is divided into organic waste and non-organic waste is mostly produced from households. Sufficient understanding is needed so that parents are able to utilize non-organic waste and use it as a learning medium for preschoolers, as well as to reduce waste and preserve nature. This study aims to describe the understanding of parents about non-organic waste and its use as a medium for learning preschoolers. The research method used is a qualitative descriptive method. Data collection techniques using interviews, observation, and documentation. Data analysis uses interactive Miles and Huberman model analysis techniques which include the stages of data collection, data reduction, data display, and data verification. Determination of the subject uses a purposive sampling technique, with criteria for families with children aged 4-6 years who are and are willing to become research respondents. The number of subjects in this study were 15 parents with these criteria located in South Tangerang, Banten. The results showed that parents' understanding of non-organic waste and its use as a learning medium were in the good category, where respondents were able to explain the meaning of non-organic waste correctly; able to distinguish by correctly mentioning the type of non-organic waste; able to explain the importance of recycling; and able to mention / give an example of learning media that can be made by utilizing non-organic waste.
\end{abstract}

Keywords: Parental, non-organic, waste, preschool

Article History: received 8 June 2020, revised 8 October 2020, accepted 13 October 2020 


\section{PENDAHULUAN}

Setiap manusia akan menghasilkan sampah sebagai produk samping dari berbagai kegiatan yang dilakukannya baik kegiatan di rumah, di kantor, di pasar, di sekolah, di pabrik, serta berbagai tempat lainnya yang tersebar di desa maupun di kota. Semakin banyak jumlah manusia disuatu tempat, akan semakin banyak aktivitas yang dilakukan, maka kemungkinan sampah yang dihasilkan juga semakin banyak. Sebagai produk sampingan dari kegiatan yang dilakukan manusia, sampah menimbulkan dampak yang tidak sedikit dan masalah yang sangat serius. Masalah tersebut timbul akibat perlakuan masyarakat terhadap sampah yang dihasilkan. Sehingga apabila datang musim penghujan, terjadi sumbatan yang mengakibatkan air kali meluap kemudian menimbulkan banjir. Dari banjir yang terjadi akibat sampah muncul masalah salah satunya kesehatan (Suryani, 2013). Masalah lain yang juga terdampak adalah masalah dalam bidang sosial, budaya, dan ekonomi.

Sampah menjadi permasalahan dunia termasuk Indonesia sebagai negara berkembang, yang harus mendapat perhatian lebih seiring laju pertumbuhan penduduk yang terus meningkat (Manik et al., 2016). Sampah itu sendiri dimaknai sebagai limbah yang tidak bernilai, bersifat padat dan terbagi ke dalam dua bagian yaitu sampah organik dan sampah non organik. Sampah organik merupakan jenis sampah yang paling banyak dihasilkan yaitu sebanyak 60 persen, sampah plastik 14 persen, sampah kertas (9\%), metal $(4,3 \%)$, kaca, kayu dan bahan lainnya $(12,7 \%)$ (Balitbang kemendagri, 2018). Berdasarkan data tersebut, dapat diketahui pula bahwa sampah non organik tidak sebanyak sampah organik, namun keberadaannya lebih sulit ditangani terutama kaleng dan plastik yang sulit terurai secara biologis oleh alam (Ifayanti et al., 2016), dan jika jumlahnya menumpuk di tanah akan mencemari lingkungan (Unilever, 2019). Kantong plastik sendiri berada di urutan ke-9 dari 10 jenis sampah yang mendominasi pesisir dunia (Qodriyatun, 2018). Berdasarkan International Coastal Cleanup Report (2017), sepuluh jenis sampah yang mendominasi pesisir dunia adalah puntung rokok (1.030.640), bungkus makanan (314.649), tutup botol plastik (276.483), botol minuman plastik (205.687), kaleng minuman (127.764), sedotan dan pengaduk plastik (125.973), botol minuman kaca (105.929), tutup botol logam (99.740), tas belanja plastik (85.079), dan kemasan plastik lainnya (77.014). Di sisi lain, proses penguraian sampah-sampah tersebut juga tidak mudah, membutuhkan waktu berpuluh tahun bahkan ratusan tahun, seperti tas belanja plastic membutuhkan waktu 10-20 tahun, botol minuman bersoda yang terbuat dari kaleng alumunium membutuhkan waktu 200 tahun, botol minuman plastic membutuhkan waktu 450 tahun, bahkan botol kaca membutuhkan waktu hingga 1 juta tahun untuk bisa hancur (Azanella, 2018).

Di Indonesia, sampah paling banyak berasal dari sampah rumah tangga (Rasio Ridho Sani dalam Prawira, 2014). Artinya, sampah dihasilkan oleh orang-orang yang banyak melakukan aktivitasnya di rumah, dalam hal ini tentunya ibu rumah tangga. Banyaknya sampah rumah tangga yang dihasilkan mengharuskan adanya pemahaman mengelola sampah yang diberikan kepada ibu rumah tangga. Pemanfaatan sampah non organik adalah salah satu yang bisa dilakukan oleh seluruh masyarakat untuk menjaga kelestarian lingkungan (Marliani, 2014). Salah satunya dengan melakukan kegiatan daur ulang. Kegiatan mendaur ulang sampah plastik dapat membuat volume timbulan sampah plastik di lingkungan berkurang (Purwaningrum, 2016). Kegiatan daur ulang menggunakan sistem pemisahan pengelolaan sampah terpadu, akan menurunkan volume sampah sebesar 33\% (Yudhistirani et al., 2015). Jika masyarakat dapat mengolah sampah dengan benar, maka akan mengurangi pencemaran lingkungan dan mendapatkan nilai ekonomi yang baik (Haifaturrahmah et al., 2017). Putra \& Yuriandala (2010) juga menyarankan agar memanfaatkan sampah plastik menjadi produk dan jasa kreatif sehingga plastik benar-benar mendukung kehidupan manusia. Di sisi lain, untuk menampung atau menyimpan sampah-sampah non organik diperlukan tempat khusus yang dinamakan bank sampah. Keberadaannya akan memudahkan bagi warga di sekitarnya untuk dapat menindaklanjuti hasil pemilahan tersebut. Adanya bank sampah yang kemudian dikelola dengan baik dan benar bukan tidak mungkin akan memberikan manfaat yang besar bagi warganya Asteria dan Heruman (2016) menuliskan bahwa Bank Sampah Pucuk Resik (BSPR) di Kampung Karangresik memberikan manfaat dengan berkurangnya timbulan sampah di komunitas, lingkungan menjadi bersih dan asri serta kemandirian warga secara ekonomi.

Namun, untuk dapat melakukan kegiatan daur ulang sampah menjadi barang yang memiliki nilai, diperlukan adanya pengetahuan dan pemahaman mengenai hal tersebut. Setyowati \& Mulasari (2013) menyebutkan bahwa ada hubungan yang sangat signifikan antara tingkat pengetahuan ibu 
rumah tangga dengan perilaku mengelola sampah plastik. Pengetahuan mendaur ulang sampah rumah tangga akan meningkatkan pemahaman dan niat individu untuk mendaur ulang sampah rumah tangganya (Dirgantara, 2013). Adanya pengetahuan dan pemahaman yang dimiliki ibu rumah tangga berdampak pada dihasilkannya berbagai produk diantaranya limbah botol plastik menjadi produk aksesoris (Doriza \& Putri, 2014) kreasi bunga artificial dari bahan botol dan sampah plastik (Diansari \& Adhivinna, 2019), serta membuat tempat gelas minuman berbahan dasar gelas minuman plastik, membuat tas dari bungkus kopi instan, serta membuat bunga dari plastik kresek (Fatoni et al., 2017).

Kenyataannya, tingkat kesadaran masyarakat akan pentingnya pengelolaan sampah dengan baik dan benar, masih rendah (Elamin et al., 2018). Kesadaran dan kepedulian masyarakat untuk mengelola sampah juga masih kurang (Kurniaty et al., 2016). Untuk itu, masyarakat perlu diberikan pemahaman tentang pengelolaan sampah berupa pengurangan dan penanganan sampah (Suryani, 2014). Terkait dengan pemanfaatan sampah non organik sebagai media pembelajaran yang dibuat ibu rumah tangga juga masih jarang ditemukan. Satu diantara yang ada adalah pembuatan boneka bantal (pillow doll) sebagai APE yang terbuat dari kain perca (Rosdiana, 2018). Meskipun media pembelajaran yang berasal dari sampah non organik memberikan banyak manfaat seperti siswa lebih peduli terhadap lingkungan sekitarnya dan lebih mudah memahami proses pembelajaran di kelas (Nurlaili et al., 2018), serta dapat memunculkan motivasi belajar anak (Susanti, 2015), namun belum terlihat media pembelajaran yang dibuat ibu-ibu rumah tangga menggunakan sampah non organik.

Media pembelajaran adalah media yang dimanfaatkan untuk membantu pendidik baik guru di sekolah maupun orangtua di rumah dalam menyampaikan berbagai informasi kepada anak didiknya. Sadiman (1993) menuliskan bahwa media adalah segala sesuatu yang dapat digunakan untuk menyalurkan pesan dari pengirim ke penerima sehingga dapat merangsang fikiran, perasaan, perhatian dan minat serta perhatian siswa sedemikian rupa sehingga proses belajar terjadi. Media pembelajaran sangat dibutuhkan dalam proses pembelajaran khususnya bagi anak prasekolah yang berada pada rentang usia 4-6 tahun. Hal ini didasarkan pada tingkat berpikir anak prasekolah yang menurut Jean Piaget berada pada tingkat pra operasional. Penggunaan media pembelajaran pada masa prasekolah bertujuan agar informasi dan stimulasi yang diberikan dapat dipahami dengan mudah oleh anak. Pentingnya penggunaan media pembelajaran menjadi salah satu prinsip pembelajaran bagi anak prasekolah yang harus dipenuhi, dan pemanfaatan alam sebagai sumber belajar menjadi hal penting lainnya. Adapun cara yang dapat dilakukan untuk menghadirkan media pembelajaran adalah dengan membeli ataupun membuat. Tersedia beragam jenis, bentuk, ukuran, dan bahan pembuat media dengan variasi warna yang menarik sebagai pilihan pengadaan media. Orangtua dapat membelinya sesuai kebutuhan, tujuan, maupun biaya yang dimiliki. Namun, kondisi saat ini menjadi salah satu alasan bagi kebanyakan orang untuk mengurangi biaya belanjanya. Cara lain yang dapat dilakukan adalah dengan membuat sendiri media sesuai kebutuhan. Untuk membuat media pembelajaran, tentu yang utama dibutuhkan adalah ketersediaan bahan, selain juga harus memperhatikan keamanannya. Dengan kreativitas yang dimiliki maka bukan tidak mungkin kebutuhan akan media pembelajaran dapat terpenuhi. Bahan yang dapat ditemukan dengan mudah diantaranya adalah bahan yang berasal dari limbah rumah tangga.

Media pembelajaran yang berasal dari limbah rumah tangga banyak ditemukan dalam pembelajaran di sekolah, dimana anak-anak diajarkan untuk membuat ataupun buatan guru yang kemudian digunakan sebagai media pembelajaran. Cukup banyak hasil penelitian yang dilakukan mengenai hal tersebut. Beberapa diantaranya adalah penelitian dengan judul kreativitas guru PAUD dalam pembuatan media pembelajaran berbasis game edukasi dari bahan alam dan limbah (Ambarita, Purnamasari, 2020), pengaruh media botol bekas terhadap kemampuan motorik halus anak kelompok B di TK PKK Setya Putra Desa Bokor Kecamatan Tumpang Kabupaten Malang (Nurani, Wijayanti, Iswahyudi, 2019), pengaruh penerapan media lego hijaiyah dari limbah tutup botol untuk meningkatkan pengenalan huruf hijaiyah di RA Miftahul Huda Kertosari Pasuruan (Holifah, Ma'ruf, 2019) serta pemanfaatan sumber belajar dengan limbah kardus untuk mengembangkan konsep matematika permulaan anak usia 5-6 tahun (studi eksperimen di TK Taman Indria Semarang) (Hayuningtyas, 2014). Selain penelitian juga banyak dilakukan kegiatan pengabdian untuk meningkatkan kemampuan guru terkait hal tersebut, diantaranya adalah pemanfaatan benda-benda di lingkungan sekitar untuk menanamkan konsep bilangan pada anak usia dini (Faizah, dkk, 2020), pemanfaatan limbah kain perca untuk mengembangkan media 
pembelajaran matematika bagi guru SD (Purwasih, Anita, Afrilianto, 2020); pendampingan bunda paud dalam pembuatan alat permainan edukatif (ape) sederhana untuk pengenalan konsep bangun datar (Susilowati, dkk, 2020); serta pemanfaatan ecobricks untuk meningkatkan pengetahuan serta keterampilan guru-guru Taman Kanak-kanak (TK) di Surakarta dalam memanfaatkan ecobricks sebagai media pembelajaran (Palupi, 2020).

Belum banyak ditemukan kegiatan penelitian dengan sasaran orangtua terkait pemanfaatan limbah rumah tangga sebagai media pembelajaran untuk anak usia dini. Sementara kenyataan yang terjadi saat ini dimana hampir seluruh warga dunia menghadapi virus covid-19, khususnya dalam dunia pendidikan, orangtua menjadi terdampak utama yang paling merasakan adanya virus tersebut. Kegiatan belajar mengajar tidak lagi dilakukan di sekolah, tetapi bergeser ke rumah dengan orangtua terutama ibu sebagai gurunya. Belajar dari rumah menjadi istilah yang sudah biasa didengar, dengan sistem pembelajaran dalam jaringan (daring) atau online sebagai sistem utamanya. Namun, meskipun pembelajaran dilakukan di rumah, prinsip pembelajaran untuk anak usia dini tetap harus diperhatikan, terutama mengenai ketersediaan akan media. Menyikapi hal tersebut, pada akhirnya orangtua dituntut pula untuk mampu memenuhi kebutuhan akan media, dan untuk mewujudkannya diperlukan pemahaman dari orangtua mengenai media itu sendiri, cara membuat, serta bahan pembuatnya.

Berdasarkan pemaparan tersebut, dan belum ditemukannya penelitian mengenai pemanfaatan limbah rumah tangga oleh orangtua sebagai media pembelajaran, maka dilakukan penelitian yang bertujuan untuk mendeskripsikan pemahaman orangtua mengenai sampah non organik dan pemanfaatannya sebagai media pembelajaran bagi anak prasekolah. Menurut Poerwodarminto (2007), pemahaman adalah mengerti benar tentang sesuatu hal. Berdasarkan kata kerja operasional bidang kognitif dalam taksonomi Bloom, pemahaman adalah (diantaranya) menjelaskan, membedakan, dan mencontohkan, sehingga yang dimaksud dengan pemahaman dalam penelitian ini adalah kemampuan orang tua untuk menjelaskan, membedakan, dan mencontohkan dengan benar mengenai sampah non organik dan pemanfaatannya sebagai media pembelajaran bagi anak prasekolah.

\section{METODE}

Sesuai dengan tujuan penelitian yang akan dicapai yaitu mendeskripsikan pemahaman orangtua mengenai sampah non organik dan pemanfaatannya sebagai media pembelajaran bagi anak prasekolah, maka metode penelitian yang digunakan adalah metode deskriptif kualitatif. Pemahaman diukur melalui kemampuan orangtua dalam menjelaskan, membedakan, dan mencontohkan sampah non organik, jenisnya, serta pemanfaatannya sebagai media pembelajaran, dengan benar. Subjek penelitian berjumlah 15 orangtua yang berlokasi di wilayah Tangerang Selatan dengan teknik penentuan sampel menggunakan purposive sampling, berdasarkan kriteria keluarga dengan anak usia 4-6 tahun serta bersedia menjadi subjek penelitian. Pengumpulan data dilakukan dengan wawancara, observasi, dan dokumentasi. Wawancara menggunakan sistem pertanyaan terbuka dilakukan dengan menggunakan pedoman wawancara yang disusun sesuai dengan variable penelitian, dan disajikan dalam bentuk google form mengingat masih diberlakukannya pembatasan sosial berskala besar di wilayah Tangerang Selatan. Untuk memperkuat data dilakukan pula observasi dan dokumentasi terhadap media-media yang tersedia di rumah yang berasal dari sampah non organik, dengan menggunakan video call dan foto-foto. Teknik analisis data menggunakan model interactive Miles and Huberman yang terdiri dari tahap data collection, data reduction, data display, dan conclusion: drawing/verifiying (Miles \& Huberman, 1994). Hasil analisis data dikelompokkan dengan tiga kategori pemahaman yaitu, baik, cukup, dan kurang, dengan kategori sebagai berikut. 
Tabel 1.

Indikator Pemahaman, Kategori, Dan Nilai Prosentase

\begin{tabular}{lcc}
\hline \multicolumn{1}{c}{ Indikator Pemahaman } & Kategori & Prosentase \\
\hline Mampu menjelaskan; & Baik & $66.7 \%-100 \%$ \\
mampu membedakan; & Cukup & $33.3 \%-66.6 \%$ \\
mampu mencontohkan & Kurang & $0.00-33.2 \%$ \\
\hline
\end{tabular}

Adapun kisi-kisi pedoman wawancara disajikan dalam tabel 2 berikut ini.

Tabel 2.

.Kisi-Kisi Pedoman Wawancara

\begin{tabular}{ll}
\hline \multicolumn{1}{c}{ Aspek } & \multicolumn{1}{c}{ Pertanyaan } \\
\hline Sampah non organik dan & Pengertian sampah non organik \\
pemanfaatannya sebagai & Jenis sampah yang dihasilkan di rumah \\
media pembelajaran & Sampah non organik yang dihasilkan di rumah \\
& Pengelolaan sampah non organik \\
& Media pembelajaran yang dapat dibuat dari sampah non organik \\
\hline
\end{tabular}

Alur penelitian ini disajikan pada Gambar 1, yakni dimulai dari perumusan permasalahn penelitian, penentuan metode dan subjek, penyusunan instrument dan pengambilan data, serta diakhiri dengan perumusan jawaban atas pertanyaan penelitian.

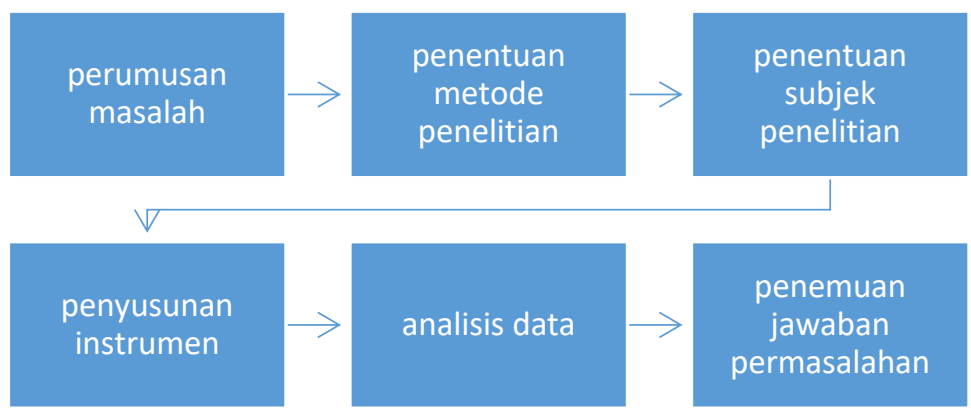

Gambar 1. Metode penelitian

\section{HASIL DAN PEMBAHASAN}

Perilaku seseorang mencerminkan pengetahuan dan pemahamannya. Penelitian ini bertujuan untuk menggambarkan pemahaman orangtua mengenai sampah non organik serta pemahaman orangtua mengenai pemanfaatan sampah non organik dalam membuat media pembelajaran bagi anak prasekolah. Pemahaman orangtua mengenai sampah non organik diketahui dari jawaban yang diberikan melalui google form. Dari 15 orang peserta, sembilan (9) diantaranya memberikan jawaban bahwa sampah non organik adalah sampah yang sulit terurai atau susah hancur, bisa didaur ulang, dan dihasilkan dari bahan non hayati. Satu (1) orang menyatakan bahwa sampah non organik merupakan sampah yang bisa hancur, seperti sampah sayuran, dan lima (5) orang lainnya tidak menjelaskan mengenai makna sampah non organik melainkan menyebutkan contoh sampah non organik yaitu kardus dan botol plastik.

Berdasarkan hasil olah data diketahui bahwa sebanyak $75 \%$ orangtua dengan anak usia prasekolah di wilayah Tangerang Selatan, menghasilkan lebih banyak sampah organik. Sementara $19 \%$ lainnya menghasilkan sampah non organik, dan sisanya 6\% tidak memberikan jawaban. Banyaknya limbah sampah organik menunjukkan bahwa kebutuhan rumah tangga memang lebih banyak pada kebutuhan sehari-hari atau kebutuhan pokok pangan berupa sayuran, lauk pauk, 
bumbu dapur, beras, buah-buahan, dan jenis makanan lainnya. Hal ini dikarenakan setiap orang akan makan paling tidak tiga kali dalam sehari, disertai dengan makan camilan yang jenisnya bermacam-macam. Meskipun dari barang-barang yang dibeli tersebut juga dihasilkan sampah non organik berupa plastik kresek sebagai wadah belanjaan namun jumlahnya tidak sebanyak sampah dari hasil organik, berupa sayuran busuk, akar sayuran, kulit bawang, kulit buah, dan lainnya yang dihasilkan setiap hari sebagai sisa olahan masakan.

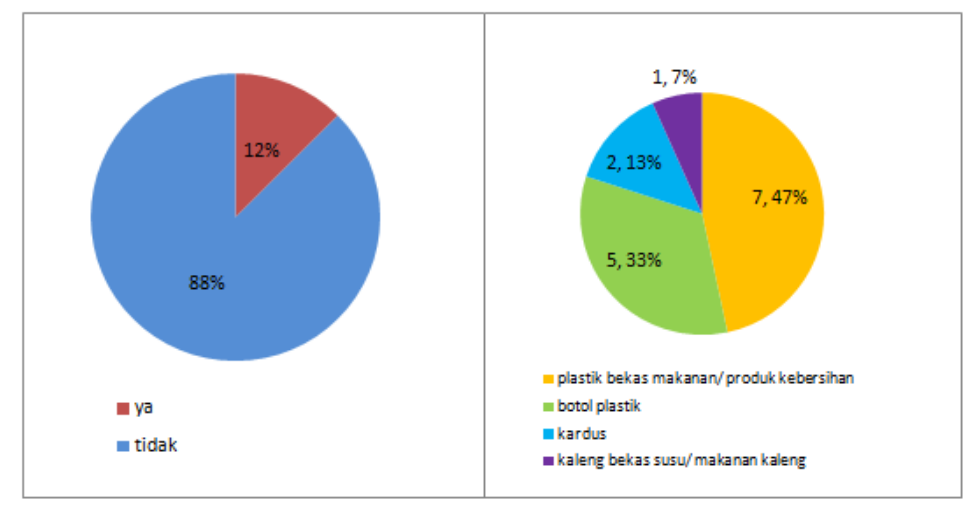

Gambar 2. Proses pemilahan sampah (kiri); Jenis sampah non organik yang banyak dihasilkan di rumah (kanan)

Selain orangtua mengetahui mengenai makna sampah non organik, mereka juga mengetahui jenis sampah non organik. Berdasarkan gambar 2 sebelah kiri, diketahui bahwa sampah jenis non organik yang disebutkan orangtua dan dihasilkan di rumah adalah plastik bekas makanan/ produk kebersihan (47\%), botol plastik (55\%), dan kaleng bekas susu atau makanan kaleng (13\%). Hanya $7 \%$ atau 1 orang yang menyebutkan bahwa sampah non organik berupa kardus. Data tersebut menunjukkan bahwa, sebanyak $99 \%$ orangtua atau responden telah mengetahui sampah apa saja yang termasuk jenis sampah non organik. Di sisi lain, berdasarkan jenis sampah yang dihasilkan menunjukkan bahwa bungkus makanan menjadi urutan kedua terbanyak setelah botol plastik, dimana data tersebut sesuai dengan informasi yang disampaikan International Coastal Cleanup Report (2017), dengan botol minuman plastik berada di urutan keempat terbanyak. Kenyataan yang mungkin belum diketahui orangtua adalah bahwa jenis sampah plastik termasuk bungkus makanan dan botol plastik merupakan jenis sampah yang tidak mudah terurai dan membutuhkan waktu yang sangat lama, dimana kantong plastik membutuhkan waktu 10-20 tahun, dan botol (minuman) plastik membutuhkan waktu 450 tahun (Azanella, 2018).

Kurangnya pengetahuan orangtua mengenai masa hancur sampah non organik terlihat dari gambar 2 dimana hanya $12 \%$ orangtua yang melakukan pemilahan antara sampah organik dan sampah non organik, sementara sebanyak $88 \%$ yang lain menyatakan tidak ada pemilahan atau langsung dibuang. Rendahnya pengetahuan, kepedulian, ataupun kesadaran akan pentingnya menjaga lingkungan. Kebiasaan membuang sampah sembarangan seringkali mengabaikan keberadaan tempat sampah yang telah disediakan. Terkadang rasa malas beranjak dari tempat seseorang berada membuat sampah diletakkan begitu saja hingga orang tersebut beranjak pergi meninggalkan sampah. Tidak adanya proses pemilahan, juga dapat dimaknai bahwa sampah yang terdiri dari sampah organik dan non organik dibuang dalam satu tempat bersamaan, sehingga pembusukan yang terjadi pada sampah organik menyatu dengan sampah non organik. Hal ini menyulitkan bagi pemulung sebagai salah satu pelaku kebersihan karena dengan pekerjaannya tersebut, lingkungan bisa sedikit terjaga akibat dikumpulkannya sampah-sampah non organik, untuk diproses lebih lanjut. 


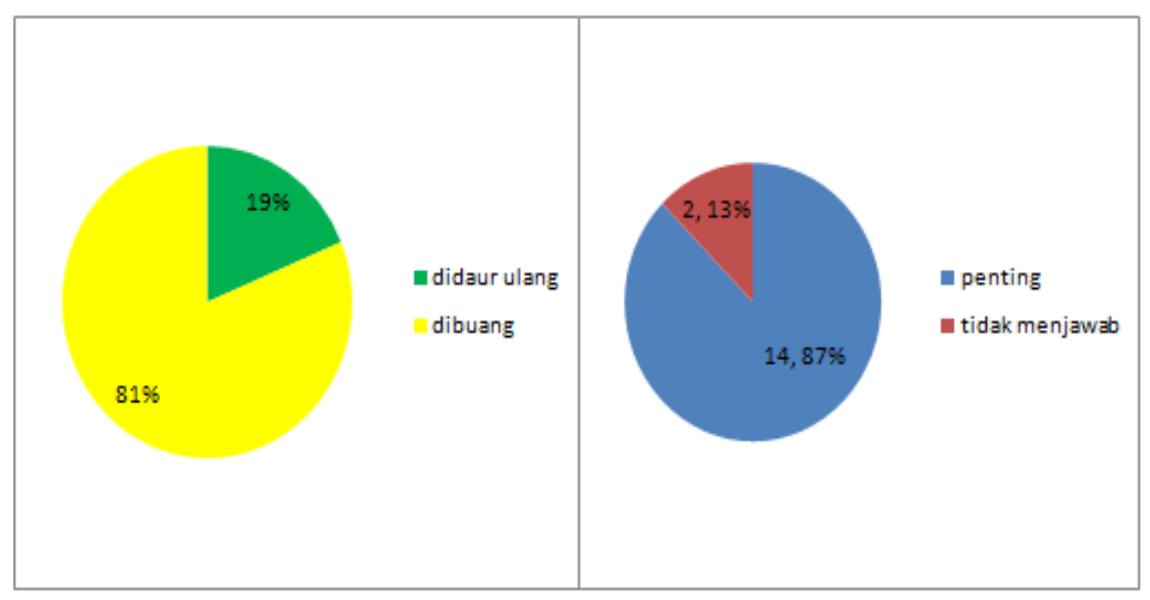

Gambar 3. Perlakuan orangtua terhadap sampah non organik (kiri); pentingnya kegiatan daur ulang (kanan)

Berdasarkan gambar 3 (kanan) terlihat bahwa $87 \%$ responden menyatakan daur ulang penting dilakukan dengan alasan agar mengurangi sampah dan sebagai bukti cinta lingkungan. Hal tersebut dapat dimaknai bahwa responden menyadari pentingnya daur ulang untuk dapat mengurangi sampah sekaligus menjaga lingkungan. Marliani (2014) menyatakan bahwa apabila pengetahuan mengenai pentingnya melakukan daur ulang dapat dilakukan dengan benar, maka bukan tidak mungkin sampah yang dihasilkan akan dapat berkurang, serta kelestarian lingkungan juga dapat terjaga. Namun pengetahuan tersebut belum diiringi dengan perilaku yang tepat, yang ditunjukkan dengan data pada gambar 3 (kiri) dimana hanya 19\% dari responden yang melakukan daur ulang, sementara $81 \%$ tidak melakukannya atau langsung membuang seluruh sampah yang ada.

Terkait dengan pemanfaatan sampah non organik sebagai media pembelajaran, berdasarkan hasil wawancara melalui google form $100 \%$ responden menyatakan bahwa sampah non organik dapat didaur ulang menjadi media pembelajaran. Pada saat responden diminta untuk menyebutkan media pembelajaran apa saja yang dapat dibuat dari sampah non organik, $20 \%$ responden menyatakan membuat krencengan dari botol bekas yang dicat dan diisi beras atau biji kacang hijau; $13.33 \%$ responden membuat mobil-mobilan dari kardus pepsodent dan botol; $13.33 \%$ responden membuat tempat sampah; $13.33 \%$ responden membuat celengan; $6.68 \%$ responden membuat vas bunga; $13.33 \%$ responden membuat tempat pensil atau pulpen, tempat sisir, tempat asesoris; dan $20 \%$ responden menyatakan tidak membuat apa-apa karena tidak bisa dan tidak mengerti harus membuat apa. Apabila dihitung secara keseluruhan maka terlihat bahwa $80 \%$ responden telah mengetahui media pembelajaran apa saja yang dapat dibuat dengan cara mendaur ulang sampah, hanya $20 \%$ yang menyatakan tidak membuat karena tidak mengetahui media apa yang dapat dibuat dari limbah sampah tersebut. Berdasarkan informasi yang ada dapat dikatakan bahwa responden memiliki pengetahuan mengenai media pembelajaran yang dapat dibuat dengan memanfaatkan sampah non organik. Hal tersebut juga menunjukkan bahwa responden telah memiliki cukup pengetahuan untuk dapat mengolah sampah. Setyowati \& Mulasari (2013) juga menyampaikan bahwa untuk dapat memanfaatkan sampah non organik sebagai media pembelajaran dibutuhkan pengetahuan dan pemahaman yang cukup untuk dapat mewujudkannya.

Terkait pembuatan media pembelajaran berbasis sampah non organik, diketahui bahwa $73.4 \%$ membuatnya sendiri di rumah, $13.3 \%$ melakukannya bersama dengan tetangga dengan didampingi pengajar, dan $13.3 \%$ tidak membuat media. Dukungan tentunya diperlukan untuk meningkatkan pengetahuan responden dalam pembuatan media pembelajaran. Selama ini, $73.4 \%$ responden membuat media di rumah masing-masing tanpa adanya pendampingan. Sehingga tidak dapat diketahui apakah media yang dibuat sudah sesuai dengan syarat membuat media dan digunakan dengan cara yang benar. Namun jika dilihat secara keseluruhan, dapat disampaikan bahwa $86.7 \%$ responden mampu membuat media pembelajaran dengan memanfaatkan sampah non organik. 


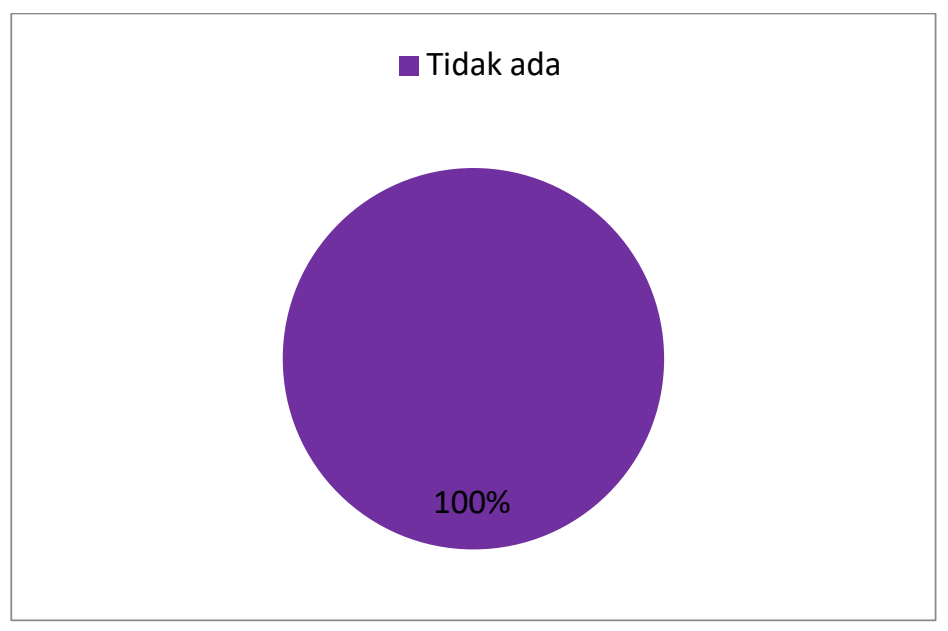

Gambar 4. Keberadaan tempat penampungan sampah non organik

Untuk mendukung pengetahuan responden mengenai pemanfaatan sampah non organik sebagai media pembelajaran juga diperlukan sebuah sarana berupa tempat penyimpanan sampah atau bank sampah yang telah dipilih untuk dapat didaur ulang. Hal ini dimaksudkan untuk menjamin ketersediaan bahan utama pembuat media yang selalu siap untuk digunakan. Namun, berdasarkan gambar 4, orangtua di wilayah Tangerang Selatan tidak memiliki tempat penampungan sampah non organik. Sehingga, meskipun orangtua telah memilah sampah, memahami pentingnya daur ulang, memiliki pengetahuan mengenai pembuatan media pembelajaran menggunakan limbah sampah, namun apabila tempat untuk menyimpan sampah non organik yang telah dipilah tidak tersedia maka bukan tidak mungkin sampah-sampah tersebut akan kembali berujung pada tempat pembuangan sampah akhir (TPA). Hal ini dikarenakan sampah yang telah dipilah tersebut mungkin tidak langsung didaur ulang. Perlu waktu khusus yang disediakan orangtua untuk dapat menggunakan sampah tersebut. Sehingga untuk sementara waktu, sampah dibiarkan menumpuk dan menunggu. Jika telah banyak dan sampah belum dapat dimanfaatkan, maka sampah tersebut akan kembali menjadi sampah yang pada akhirnya akan dibuang karena memenuhi ruangan. Terlebih jika di rumah tidak memiliki gudang atau tempat penyimpanan sampah. Padahal berdasarkan hasil penelitian yang dilakukan Asteria \& Heruman (2016), keberadaan bank sampah akan sangat memberikan dampak positif bagi warga sekitarnya, yang diantaranya adalah berkurangnya timbulan sampah, lingkungan menjadi lebih bersih dan asri, serta kemandirian warga secara ekonomi. Tentunya perubahan secara ekonomi akan terjadi apabila sampah tersebut dimanfaatkan secara maksimal dan memiliki nilai jual.

\section{PENUTUP}

Sampah masih menjadi tantangan dan sumber masalah yang belum dapat diatasi dengan maksimal, khususnya mengenai sampah non organik. Salah satu upaya yang dapat dilakukan adalah dengan mengolahnya menjadi benda yang bermanfaat seperti membuat media pembelajaran. Berdasarkan hasil penelitian dan pembahasan di atas, dapat disampaikan bahwa $60 \%$ responden mampu menjelaskan makna sampah non organik dengan benar; $93.3 \%$ responden mampu membedakan dengan cara menyebutkan jenis sampah non organik dengan benar; $87 \%$ responden mampu menjelaskan pentingnya melakukan daur ulang; $80 \%$ responden mampu menyebutkan/ mencontohkan media pembelajaran dengan memanfaatkan sampah non organik; dan $86.7 \%$ mampu membuat media pembelajaran dengan memanfaatkan sampah non organik. Berdasarkan hal tersebut maka dapat disimpulkan bahwa responden yaitu orangtua telah memiliki pemahaman mengenai sampah non organik dan pemahaman mengenai pemanfaatan sampah non organik sebagai media pembelajaran dengan kategori baik. Namun, perilaku memilah sampah baru ditunjukkan oleh $12 \%$ responden dan perilaku mendaur ulang sampah baru dilakukan oleh $19 \%$ responden. 


\section{UCAPAN TERIMAKASIH}

Terimakasih disampaikan kepada lembaga penelitian dan pengabdian kepada masyarakat Universitas Al Azhar Indonesia atas pendanaan dalam skema competitive public service grant yang diberikan, serta orangtua di wilayah Tangerang Selatan yang telah berkenan menjadi responden dalam penelitian ini.

\section{DAFTAR PUSTAKA}

Ambarita, Jenri; Purnamasari, Ica. (2020). Kreativitas Guru Paud Dalam Pembuatan Media Pembelajaran Berbasis Game Edukasi Dari Bahan Alam Dan Limbah. DIDAXEl: Jurnal Pendidikan, Volume 1, Nomor 1.

Asteria, Donna., Heruman, Heru. (2016). Bank Sampah Sebagai Alternatif Strategi Pengelolaan Sampah Berbasis Masyarakat Di Tasikmalaya. Jurnal Manusia dan Lingkungan. Vol 23 No 1. Doi: $10.22146 / J m l .18783$.

Https://Www.Researchgate.Net/Publication/314109407_Bank_Sampah_Sebagai_Alternatif_Strate gi_Pengelolaan_Sampah_Berbasis_Masyarakat_Di_Tasikmalaya_Bank_Sampah_Waste_B anks_As_An_Alternative_Of_CommunityBased_Waste_Management_Strategy_In_Tasikmalaya [Accessed Jun 07 2020].

Azanella, Luthfia Ayu. (2018). Butuh Waktu Lama bagi Bumi untuk Mengurai Sampah dan Plastik. https://sains.kompas.com/read/2018/11/21/174018423/butuh-waktu-lama-bagi-bumi-untukmengurai-sampah-dan-plastik?page $=2$.

Diansari, RE., Adhivinna, VV.,. (2019). Pendampingan Dan Pelatihan Pemanfaatan Limbah Masyarakat Menjadi Produk Bernilai Guna Tinggi Kepada Ibu Rumah Tangga Yang Tergabung Dalam Rumah Kreasi Castle Dengan Binaan Dinas Lingkungan Hidup. Doi: 10.31316/Jbm.V1i1.222

https://www.researchgate.net/publication/335590576_Pendampingan_Dan_Pelatihan_Pemanfaata n_Limbah_Masyarakat_Menjadi_Produk_Bernilai_Guna_Tinggi_Kepada_Ibu_Rumah_Tangg a_Yang_Tergabung_Dalam_Rumah_Kreasi_Castle_Dengan_Binaan_Dinas_Lingkungan_Hi dup

Dirgantara, I Made Bayu. (2013). Pengetahuan Mendaur Ulang Sampah Rumah Tangga Dan Niat Mendaur Ulang Sampah. Jurnal Studi Manajemen \& Organisasi Volume 10, No1.

Doi:Https://Doi.Org/10.14710/Jsmo.V10i1.5572Https://Ejournal.Undip.Ac.Id/Index.Php/Smo/Article/ View/5572.

Doriza, Shinta., Putri, Vera Utami Gede. (2014). Pemanfaatan Limbah Botol Plastik Melalui Pelatihan Wirausaha Produk Aksesoris Bagi Ibu Rumah Tangga. Sarwahita: Jurnal Pengabdian Kepada Masyarakat. Vol 11 No 2. DOI: https://doi.org/10.21009/sarwahita.112 http://journal.unj.ac.id/unj/index.php/sarwahita/issue/view/447

Elamin, MZ., Ilmi, KN., Tahrirah, T., Zarnuzi, YA., Suci, YC., Rahmawati, DR., Kusumawardhani, R., P. Dimas MD., Rohmawati, RA., Bhagaskoro, PA., Nasifa, IF., (2018). Analisis Pengelolaan Sampah Pada Masyarakat Desa Disanah Kecamatan Sreseh Kabupaten Sampang. Jurnal Kesehatan Lingkungan, Vol.10, No.4, Hal: 368-375.

Faizah, Hanim; Syukron, Moh. Maftuh; Silviana; Purwasih Maya; Dwi, Annisa; Sulistyaningtyas. (2020). Pemanfaatan Benda-Benda di Lingkungan Sekitar untuk Menanamkan Konsep Bilangan pada Anak Usia Dini. Jurnal Solma, Vol. 9 No. 1.

Fatoni, Nur., L. Rinaldy Imanuddin., Darmawan, Ahmad Ridho. (2017). Pendayagunaan Sampah Menjadi Produk Kerajinan. DIMAS - Volume 17, Nomor $1 . \quad$ DOI: http://dx.doi.org/10.21580/dms.2017.171.1505.

Haifaturrahmah., Nizaar, Muhammad., Mas'ad. (2017). Pemanfataan Botol Plastik Bekas Sebagai Media Tanam Hidroponik Dalam Meningkatkan Kesadaran Siswa Sekolah Dasar Terhadap 
Lingkungan Sekitar. Jurnal Ummat Vol. 1, No. 1, Hal. 10-16. Issn 2598-8158 Doi: Https://Doi.Org/10.31764/Jmm.V1i1.8.

Hayuningtyas, Hesti. (2014). Pemanfaatan Sumber Belajar Dengan Limbah Kardus Untuk Mengembangkan Konsep Matematika Permulaan Anak Usia 5-6 Tahun (Studi Eksperimen Di Tk Taman Indria Semarang). Early Childhood Education Papers (Belia), Vol 3, No 1.

Holifah, Nur; Ma'ruf, Ahmad. (2019). Pengaruh Penerapan Media Lego Hijaiyah Dari Limbah Tutup Botol Untuk Meningkatkan Pengenalan Huruf Hijaiyah Di RA Miftahul Huda Kertosari Pasuruan. Jurnal Mu'allim, Volume 1 Nomor 1.

International Coastal Cleanup 2017 Report. (2017). Together for Our Ocean. https://oceanconservancy.org/wp-content/uploads/2017/06/International-CoastalCleanup_2017-Report.pdf

Kurniaty, Yulia., Nararaya, WHB., Turawan, RN., Nurmuhamad, Fendy. (2016). Mengefektifkan Pemisahan Jenis Sampah Sebagai Upaya Pengelolaan Sampah Terpadu Di Kota Magelang. Varia Justicia. Vol 12 No. 1.

Miles, Matthew B., Huberman, A. Michael. (1994). An Expanded Sourcebook Qualitative Data Analysis. Second Edition. United States of America: Sage Publications. International Educational and Professional Publishers. Hal. 12. https://books.google.co.id/books? id=U4IU_wJ5QEC\&printsec=frontcover\&dq=sugiyono+2013+metode+penelitian\&hl=en\&sa=X\&ved=0a hUKEwjZkPaxiPHpAhXCW3wKHdTsC5wQ6AEIKjAA\#v=onepage\&q\&f=false

Marliani, Novi. (2014). Pemanfaatan Limbah Rumah Tangga (Sampah Non organik) Sebagai Bentuk Implementasi Dari Pendidikan Lingkungan Hidup. Jurnal Formatif 4(2). Doi: Http://Dx.Doi.Org/10.30998/Formatif.V4i2.146.

Https://Journal.Lppmunindra.Ac.Id/Index.Php/Formatif/Article/View/146/140

Manik, Rehito Traro Hiro Karo., Makainas, Indradjaja., \& Sembel, Amanda. (2016). Sistem Pengelolaan Sampah Di Pulau Bunaken. Spasial: Perencanaan Wilayah dan Kota Vol. 3 no 1, h. 15-24.

Nurani, Ratna Candra; Rinawijayanti; Iswahyudi, Didik. (2019). Pengaruh media Botol Bekas Terhadap Kemampuanmotorik Halus Anak Kelompok B Di TK PKK Setya Putra Desa Bokor Kecamatan Tumpang Kabupatenmalang. Prosiding Seminar Nasional Pendidikan Dan Pembelajaran Bagi Guru Dan Dosen , Vol. 3. Halaman 828 - 832

Nurlaili, Shofiyatun., Supriatna, Nana., Sapriya. (2018). Pengenalan Eco-Literacy Melalui Media Pembelajaran Dari Sampah Di Sekolah Dasar. Al-Mudarris Journal of Education. Vol. 1 No. 2. Http://E-Journal.Staima-Alhikam.Ac.Id/Index.Php/Almudarris/Index

Purwaningrum, Pramiati. (2016). Upaya Mengurangi Timbulan Sampah Plastik Di Lingkungan. Indonesian Journal Of Urban And Environmental Technology. Vol 8 No. 2. Doi: Http://Dx.Doi.Org/10.25105/Urbanenvirotech.V8i2.1421.

Putra, Hijrah Purnama., Yuriandala, Yebi. (2010). Studi Pemanfaatan Sampah Plastik Menjadi Produk Dan Jasa Kreatif. Jurnal Sains Dan Teknologi Lingkungan. Vol 2, Nomor 1. Halaman 21-31. Doi: 10.20885/Jstl.Vol2.Iss1.Art3

Prawira, Aditya Eka. (2014). Sampah di Indonesia Paling Banyak Berasal dari Rumah Tangga. https://www.liputan6.com/health/read/831503/sampah-di-indonesia-paling-banyak-berasaldari-rumah-tangga

Purwasih, Ratni; Anita, Ika Wahyu; Afrilianto, Muhammad. (2020). Pemanfaatan Limbah Kain Perca untuk Mengembangkan Media Pembelajaran Matematika bagi Guru SD. Jurnal SOLMA Vol. 09, No. 1. doi: http://dx.doi.org/10.29405/solma.v9i1.3650

Pusat Pelatihan Dan Pemberdayaan Masyarakat (P3M). (2014). Pengelolaan Sampah Mandiri Ramah Lingkungan Skala Rumah Tangga Studi Khasus Desa Cupang. Scientiae Educatia. Volume 3 Nomor 1. 
Poerwadarminta. (2007). Kamus Besar Bahasa Indonesia. Jakarta: Balai Pustaka.Ridwan, Ifayanti., Nurfaida., Mantja, Katriani. (2016). Pemanfaatan Sampah Non organik Menjadi Produk Berdaya Guna. Jurnal Dinamika Pengabdian. Vol 1 No 2.

Qodriyatun, Sri Nurhayati. (2018). Sampah Plastik: Dampaknya Terhadap Pariwisata dan Solusi. Info Singkat Bidang Kesejahteraan Sosial Kajian Singkat terhadap Isu Aktual dan Strategis. Vol X No 23.

Ridwan, Ifayanti; Nurfaida; Mantja. Katriani. (2016). Pemanfaatan Sampah Non organik Menjadi Produk Berdaya Guna. Jurnal Dinamika Pengabdian. Vol. 2 No. 1.

Rosdiana, Aliva., Yulistianti, HD., Laila, AN. (2018). Pelatihan Pemanfaatan Kain Perca Sebagai APE Pillow Doll Untuk Pembelajaran Anak Usia Dini Di Kuwasen Jepara. Journal of Dedicators Community Unisnu JeparaVol. 2 No. 1. DOI: https://doi.org/10.34001/jdc.v2i1.659

Suryani, Anih Sri. (2013). Mewaspadai Potensi Penyakit Pascabanjir. Info Singkat Kesejahteraan Sosial. Vol. V, No 03. http://berkas.dpr.go.id/puslit/files/info_singkat/Info\%20Singkat-V-3-IP3DI-Februari-2013-67.pdf.

Suryani, Anih Sri. (2014) Peran Bank Sampah Dalam Efektivitas Pengelolaan Sampah (Studi Kasus Bank Sampah Malang), Jurnal Aspirasi 5 (1), 71-84.

Setyowati, Ririn., Mulasari, SA., (2013). Pengetahuan Dan Perilaku Ibu Rumah Tangga Dalam Pengelolaan Sampah Plastik. Kesmas. National Public Health Journal. Vol 7. No.12. Doi: Http://Dx.Doi.Org/10.21109/Kesmas.V7i12.331

Susanti, Marlin Dwi. (2015). Pemanfaatan Media Pembelajaran Terhadap Motivasi Belajar Anak TK. Jurnal Pendidikan Anak, Volume IV, Edisi 2

Susilowati, Eka; Fathonah, Nur; Astutik, Erna Puji; Hadi, Susilo; Prayitno, Lidya Lia. (2020). Pendampingan Bunda PAUD dalam Pembuatan Alat Permainan Edukatif (APE) Sederhana untuk Pengenalan Konsep Bangun Datar. Jurnal SOLMA Vol. 09, No.1, Doi: http://dx.doi.org/10.29405/solma.v9i1.4714

Unilever. (2019). Panduan Pemilahan Sampah Di Rumah. Https://www.Unilever.Co.Id/Id/Images/Panduan-Pemilahan-Sampah-2019_Tcm1310543969_1_Id.Pdf

Yudhistirani, Sri Anastasia., Syaufina, Lailan., Mulatsih, Sri. (2015). Desain Sistem Pengelolaan Sampah Melalui Pemilahan Sampah Organik Dan Non organik Berdasarkan Persepsi Ibu - Ibu Rumah Tangga. Konversi. 2015. Vol 4 No 2.Doi: Https://Doi.Org/10.24853/Konversi.4.2.29-42. 